\title{
3. DNAメチル化による矮性発現の制御
}

\section{佐野 浩}

秋田県立農業短期大学附属生物工学研究所

\section{遺伝子の多くは沈黙している}

高等動物のゲノムには約 $3 \times 10^{9} \mathrm{bp} の \mathrm{DNA}$ が含まれ ており，これは $2 \times 10^{6}$ 個の遺伝子をコードできる量で ある. しかしヒトの場合, 遺伝的解析から遺伝子の総数 は 5 万〜 10 万程度と考学られている。つまり，約 $95 \%$ の DNA はRNA に転写されない，どうといらことすな い存在らしい，高等植物の場合も状況は似たようなもの でトウモロコシでは 80\% 以上の DNA が単純な繰返 し配列で構成されているという.イネのDNA はゲノム 当りヒトの $1 / 10$ 程度とされるが，遺伝子の総数もヒト の1/10 とは限らない. しかし，ヒトより多いといらこ とはないはずで，真核細胞生物の平均遺伝子数の約 3 万 くらいであろらか.これらの遺伝子も常時転写されてい るわけではない，組織や生長の各段階に特いて一時に発 現される遺伝子は house-keeping 遺伝子を含めても多 くて数千のオーダーであろう．約 70\% 以上の遺伝子は 転写されないswitch-off の状態にあることになる，発 生のある段階である遺伝子が特異的に発現されるが，次 の段階では発現されなくなる，その代わり，それまで 沈默していた別の遺伝子が活発に発現されるようになる ……こうこした遺伝子発現のダイナミックな制御の連続 によって，生命体は正常に分化・生長できるのである.

遺伝子制御のダイナミズムには，もら一つの面もあ る. 動物も植物も地球上の様々な環境要因にさらされて むり，生命を維持するためには常に細心の注意（！）を もって環境変化に対応しなければならない.シロイヌナ ズナArabidopsis では機械的な接触や急速な乾燥によっ て数分以内に発現される遺伝子が発見されている。一種 の自己防禦系が作動したと考えられるが，なぜかくも素 早いシグナル応答ができるのかは不明である(1,2).

\section{遺伝子発現の調節には DNA メチル化が関わって いる}

ある遺伝子が特異的に転写されるかされないかは，何 によって決定されるのだろらか？遺伝子のプロモータ 一区域に結合する転写調節因子による制御が第一に考 えられる.これらの調節因子として, 現在までのとこ ろ, 特異的な構造をもつ 3 種類の蛋白質群が同定されて いる.すなわわ, DNA に結合しやすい helix-turn-helix 構造, zinc-finger 構造, leucine-zipper 構造であ る ${ }^{(3,4)}$. これらの蛋白質の特異的な解離・結合によって, 転写が switch-on/off されるわ忷であるが，この調節機 構は遗伝子の側から見れば完全に受動的である. 次に考 えられるのは遺伝子そのものの鞲造変化によって転写調 節を行なうもので, 能動的な機構である. 必要条件とし て, 可逆的であること, 遺伝すること, 組織特異性のあ ることなどが求められる.

巨大な DNA 分子に詨して上記の条件を満たす因子 はほとんど存在しないが, 唯一の例外としてDNAのメ チル化が考えられる. 真核細胞生物の場合, DNA のメ チル化とはシトシンの 5 位の水素がメチル基に置換した 5ーメチルシトシン $\left(\mathrm{m}^{5} \mathrm{C}\right)$ を指す. $\mathrm{m}^{5} \mathrm{C}$ は DNA の高 次構造を変えることが知られている. 1970 年代以後の 多くの実験研究によって, 活発に転写活動を行なってい る遺伝子では多かれ少なかれ $\mathrm{m}^{5} \mathrm{C}$ の量が減少している ことが示されている(これらについては別の総説を参照 されたい(5 7)). 当初, $\mathrm{m}^{5} \mathrm{C}$ は RNA ポリメラーゼの結合 を妨害するのではないかと考えられたが，賛否両論，例 外続出ではっきりした結論は得られていない, 最近, あ る種の遺伝子ではプロモータ一区域内の $\mathrm{m}^{5} \mathrm{C}$ が第一に 述べた転写調節因子の結合を調節しているといら実験 結果が得られ始めた。転写調節はこうしたすべての fac- 
tor の複雑でしかも整然とした協同作業によってなされ る，といらごく常識的な結論が得られそうである.

DNA メチル化を操作することによって矮性植物 が得られる

植物生理学で扱う典型的な矮性植物とは，正常と比較 して背丈のみ低く，他の形質は添とえど变わりない植物 体を指す.こうした矮性形質は遺伝し, 単一遺伝子の变 化によるものも少なくない。しかし矮性発現は，たとえ 単一遗伝子の欠陷が引き金になるにしても，全体として は初期遺伝子の異常が次々と連鎖反応的に他の遺伝子発 現に影響を及ぼした結果と考学られる，生長に関わる遺 伝子がぞのくらいあるすのか，現在のところ明らかなデ 一タはないが，遺伝的解析によると 1 種の植物当り少な

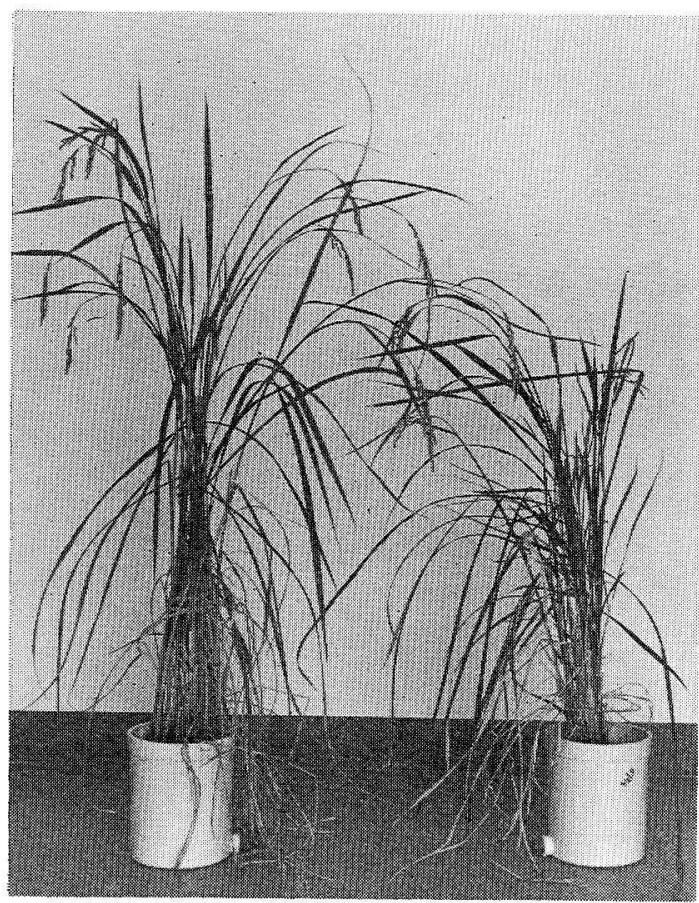

図 1 - AzaC 処理によるイネの矮化

発芽 3 日目に $0.3 \mathrm{~mm}$ azaC で 3 日間処理後，普通に播種，育 成したギンボウズ (右)，杼よび未処理対照(左)(9).

表 1 ロイネ(ギンボウズ) に対する $\mathrm{azaC}$ 処理の影響(9)

\begin{tabular}{lll}
\hline 形質 & 無処理 (対照) & $\mathrm{azaC}$ 処理 $(0.3 \mathrm{~mm})$ \\
\hline 秙長 $(\mathrm{cm})$ & $109.1 \pm 0.3$ & $96.3 \pm 5.8$ \\
出穂期 (播種後の日数) & 146 & 152 \\
穗長 $(\mathrm{cm})$ & $18.5 \pm 1.7$ & $16.0 \pm 0.9$ \\
千粒重 $(\mathrm{g})$ & $26.6 \pm 2.0$ & $26.8 \pm 3.6$ \\
\hline
\end{tabular}

生育は 3〜8 月にかけて温室で行なった。
くとも 60 以上はあると推定されている.筆者らは, “矮 性ではこれらの遗伝子群の発現様式が正常とは異なるは ずである”といら仮定に基づいて矮性に括污る遺伝子発 現制御機構を調べてきた。 その結果，DNA のメチル化 現象が正常と矮性との間で異なり，遗伝子発現の調節に 関わっていることを見いだしたので以下に紹介したい （初期の仕事についてはすでに本誌で述べている(8)ので, ここではごく簡単にふれるにとどめる).

DNA メチル化の生理作用を調べる場合，5-アザシチ ジン $(\mathrm{azaC})$ という薬版がよく使われる．5位の崖素が 室素に置換しているので in vivo でのィチル化の標的に ならず，結果的に全 DNA の脱メチル化を促すからであ る. 動物細胞の系ではよく使われ，細胞の分化や形態变 化を誘発することが知られている．植物での実験例は少 ないが，筆者らが発芽時のトウモロコシとイネの種子を 短時間 $\mathrm{azaC}$ で処理したのら普通に栽培したところ，成 熟時に草大が 15\% 注ど減少した秼が得られた（図 1).

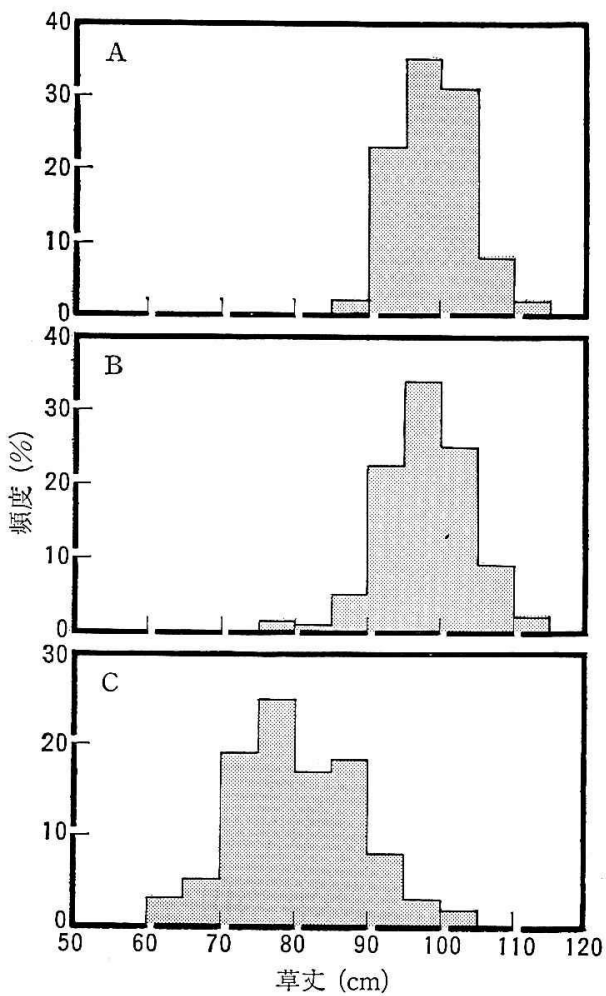

図 2 a AzaC 処理によって生じた矮性型ギンボウズの $\mathbf{M}_{2}$ 世代の草文分布

$\mathrm{A}$ : 末処理対照 (10 株) より生じた $\mathrm{F}_{2}(n=52), \mathrm{B}: \mathrm{azaC}$ 処 理親より得た正常型 $\mathrm{M}_{1}$ (13 株) より生じた $\mathrm{M}_{2}(n=271), \mathrm{C}$ : azaC 処理親より得た矮性型 $M_{1}$ (6 株) より生じた $M_{2}(n=59)^{(9)}$. 
形態的には草丈の減少が目立つだけ

で，他の形質は正常型と差が見られ なかった（表 1). 植物生理学でいう 典型的な矮性である. 自家受粉によ る $\mathrm{M}_{1}$ 世代では, 正常型と矮性型の 両形質が約 2 対 1 の割合で現われ た. 正常型 $M_{1}$ の次世代 $M_{2}$ はす べて正常型であったが，矮性型 $M_{1}$ の次世代 $\mathrm{M}_{2}$ ではすべてが矮性型で あった（図 2)，以後，矮性 $\mathrm{M}_{2}$ より 得た $\mathrm{M}_{3}, \mathrm{M}_{4}, \mathrm{M}_{5}$ まですべてが矮 性形質を示したので， azaC によっ て誘導された矮性は安定に遺伝する ことがわかった（表 2).

これまでに知られている矮性は植 物ホルモン，特にジベレリン（GA）の合成あるいは利 用系の欠損によるものが少なくない，そこで，筆者らの 得た矮性についてGA に対する感受性を調べたところ， 感受型と非感受型の 2 系統に 分類された。，一方，内在 DNA のメチル化のレベルを測定したところ，未処理対 照では 14〜15\% のントシン（C）が $\mathrm{m}^{5} \mathrm{C}$ であった。 処理植物では $11 〜 12 \%$ であったので，全Cでは $3 \%$, $\mathrm{m}^{5} \mathrm{C}$ としては約 $15 \%$ の減少である(表 3). この $\mathrm{m}^{5} \mathrm{C}$ の減少は， $\mathrm{M}_{1}, \mathrm{M}_{2}, \mathrm{M}_{3}$ 屯で安定に受け継がれた（表 $3)^{(9)}$. このことは生物学的に 2 つの興味深い意味をもっ ている.すなわち，第一に azaC が遺伝子発現レベルで 作用したことであり，DNA のメチル化の状態が生長に 関する遺伝子発現の調節に深く関わっていることを示唆 する．第二に，影響を受けた遺伝子がこれまで知られて いるイネの矮性遺伝子と同一のものか，異なるものかと いら興味である．話の都合上，第二の点から検討してみ よう。

\section{得られた矮性イネは新しい半矮性遺伝子によるの かもしれない}

イネの矮性遺伝子として分子生物学的に単離同定され たものは現在のところ知られていないが，遗伝解析の結 果から 54 個（d1 d d 60）の遺伝子座が報告されている. しかし，かなりの遺伝子が重複あるいは同じリンケージ グループに属するので実際の数はもっと少ないと思われ る. しかも, これらのらち栽培上有用な半矮性遺伝子は
さらに少ない， $d 35$ (タンギンボウズ）はジベレリン合 成系に関わる遺伝子の欠損に上る半矮性とされ，現在 の有用品種のいくつかに利用されている. $s d 1$ ( $d 47$, DGWG）はもともとインディカ種で見いだされたもの だが，レイメイをはじめ多数の半矮性栽培品種に含まれ ていることが後の調查で明らかになった。というょり， $s d 1$ 以外の半矮性遺伝子をもつ多収性栽培品種は注之え ぞない，と言った汪らが適切である，有用なイネの半矮 性品種を創り出すことは世界中で求められている課題で あるが，このように半矮性遺伝子の数が限られているこ そは遺伝的多様性が少ないことを示しここれからの育種 の障害になるか子知れない(10).

筆者らの得た矮性イネが遗伝的に完全に固定されたか ぞうかは，今後の栽培試験を待たなければならないが， それとは別にジベレリン非感受型 $\left(\mathrm{GA}^{\mathrm{i}}\right)$ の系統は上述 の $d 35, s d 1$ とは異なると思われる. $d 35, s d 1$ ともに ジベレリンには強く反応するからである，むし $\mathrm{GA}^{1}$ 系 統がコムギの Rht 3 やトウモロコシの $D 8$ (ともに GA 非感受性）飞似た矮性遺伝子をもつものなら，たと元 れが一時的に発現されたものであっても今のらちにそれ を同定，単離することによってイネに拈ける新しい半矮 性遺伝子を創出できるかも知れない．

\section{$r a s$ 関連遺伝子が得られた}

$\mathrm{AzaC}$ によって矮性が誘導されたことは，生長に関わ る遺伝子のどれかがその発現様式に変化をこうむったこ 
$\operatorname{rgp} 1$

Sp-ypt3 ara

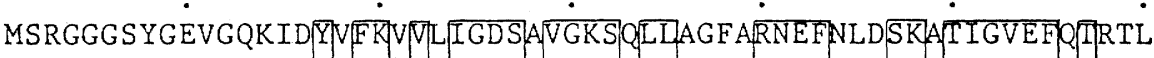
MCQEDEYDYLFKTVLI I D S GVGKS NLL MR FTRNE FN IESKSSTIGVE FATIRN I

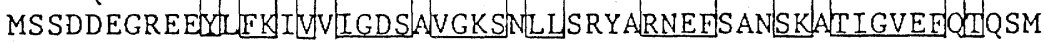

80

100

120

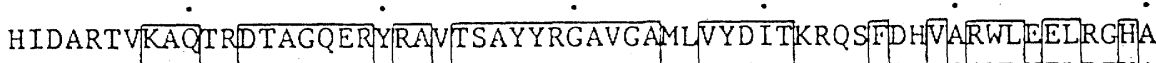

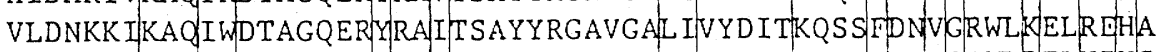
EIEGKEVKA OIWDTAGQER FRAVIS AYYRG AV GAL VVYD ITRRTIEE SUGRWLDELKIHS

140

160

180

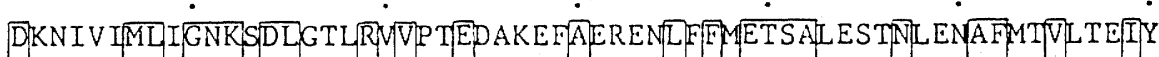
DSNIVIMLVGNKTDLL LLRAVISTEEAQA AAAENNLS FI ETS AMDASNVEEAFQTVLTEIF

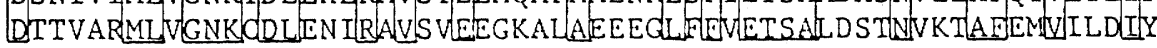

200

220

RIVSKKNIVANEEVDSSGNSSLLKGTKIVVPGQEPAPPTKASCGMS

RIVSNRSLEAGDDGVHPTAGQTLNIAPTMNDLNKKKSSSQCC,

NNYSRKQLNSDTYKDELTVNRVSLVKDDNSASKQSSGFSCCSST

図 3 m ras 関連遺伝子 rgp 1 の cDNA より推定されるアミノ酸配列と類似蛋白質とのホモロジー比較(11)

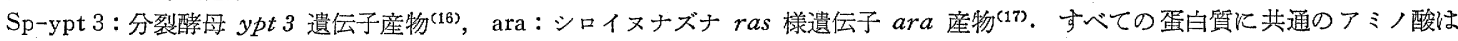
ブロックで围んである. IGDS (24)，および DTAGQER (73) は GTP のリン酸結合部位，NKXDL (131) および ETSA (159) は グアニン環の結合部位とされている.C末端近くの 2 個のシスティン (CC) はファルネシル基を介して膜脂質へ結合する部位であり， すべての ras 蛋白筫に保存されている.

とを意味する，azaC によってある遺伝子は転写活性が 促進され，別の遺伝子では逆に抑制されたはずである。

もしこの仮定が正しいとすると，正常と矮性との間で遺 伝子産物，すなわち mRNA の比較から特定遺伝子が同 定できるかも知れない，こうした仮定に基づいて，筆者 らはまず正常，矮性それぞれから mRNA を抽出し，in vitro での 翻訳生成物である蛋白質を二次元電気泳動で 調ベた．合成されたペプチドには数個を除いて両者間に ほとんぞ差が認められなかった．差の西ったペプチドの あるものは azaC 処理によって増加したもの, あるいは 減少したものであった．これらの遺伝子を単離するため に正常, 矮性それぞれから cDNA のライブラリーを作 って両者の違いを調べたところ, 約 2 万個のプラークか ら幾つかの特異クローンが同定された。これらをプロー ブとして正常と矮性の mRNA を定量したところ, azaC 処理によって活性が増加したものと, 逆に減少したもの の両方が得られた，そこで得られたクローンの塩基配列 を調べて性格づけを行なった。
矮性株で mRNA 量の増加したクローンは, 約 $1.1 \mathrm{~kb}$ で $30 \mathrm{kDa}$ の蛋白質をコードする．ホモロジー比較か ら，これまで報告されたことのない新しい遺伝子であ ることがわかった，一方， mRNA の減少したクローン は約 $1.3 \mathrm{~kb}$ であり，25kDa の蛋白質をコードする. 同様なホモロジー比較から，この蛋白質は動物のプロト 癌遺伝子産物である ras 蛋白質に相似していた ${ }^{(11)}$ ：ras 蛋白質は広く生物界に分布して拈り，艺の構造と機能 から，幾つかのサブグループに分類される、イネから 得られた ras 類似蛋白質 $\operatorname{rgp} 1$ は, 分裂酵母 Schizosaccharomyces pombe から得られた ypt 3 蛋白質に最も 高いホモロジーを示した. シロイヌナズナ Arabidopsis より同定された ras 様遺伝子から推定されるアミノ酸 配列ともホモロジーがあり，これら 3 種の蛋白質は ras

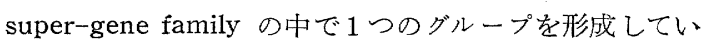
ると思われる（図 3).

ras 関連遺伝子産物は，癌誘発遺伝子として発見され た約 $20 \sim 25 \mathrm{kDa}$ の GTP 結合蛋白質である. 真核細胞 
生物に特異的に存在し, 酵母菌, 粘菌, 昆虫, 哺乳類 などから 20 種以上の類似蛋白質が同定されている。 GTP の水解エネルギーを利用して自らの高次構造を変 え，細胞内での情報転換・伝達系 (ras グループ), あ るいは細胞内物質翰送 (ypt グループ) に関わっている 可能性が挙げられている. ras グループ蛋白質はプラズ マ膜に結合して和り，GTP を結合した時の高次構造の みを認識する GAP (GTPase Activating Protein) と の相互作用によってシグナル転換を行なっているのでは ないか，と推察されている. ypt グループ䨞白質は小胞 体 (ER) やゴルジ体の膜に見いだされ，これらの構造 物上で合成される様々な物質一蛋白質, 多糖類, 脂 質など——て゚ラズマ膜へ輸送する小胞（vesicle）の 動きに関係している，と考えられている. 小胞を吘便袋 にたとえれば，ypt蛋白質はその荷札であって，中味， 輸送経路, 行先の指定を行なっているのではないだろら 力. (12,13).

植物における ras 関連遺伝子は現在のところシャイヌ ナズナより ara (前出), ara 2 5 が genomic DNA よ り同定されている. サザンブロット分析によってトウモ ロコシより ras 様配列の存在が推定された，G蛋白質様 の高分子 GTP 結合蛋白質は抗体結合法によってトウモ ロコシ, 大麦, エンドウ豆, ヘリア ンサス，シロイスナズナなどからも 発見されている.これらの結果は植 物にも動物同様 ras 抢よび G蛋白質 が存在することを明らかにしている が，攵の生理機能についてはまった く研究されていない.

酵母の RAS はアデニルシクラー ゼの活性調節を経て細胞分裂をニン トロールしていることが知られてい る. 植物でも CAMP が生長に関与 しているのではないかといら仮定の もとに, Hilson らは酵母の RAS2を タパニ細胞に導入して生成蛋白質の 影響を調べている.その結果, プロ トプラストの分裂を抑制したばかり でなくホルモン代謝にまで影響を与 えることがわかった(14). しかし， cAMP-ras 蛋白質の 関係は酵母以
外では否定されているので，植物におけるこの研究の意 義は別に再検討されなくてはならない.いずれにしても 植物に拈ける ras 遗伝子, 衿よびその産物の研究は始ま ったばかりで, 今後の発展が待たれる.

\section{$\operatorname{rgp} 1$ はイネの生長に関与しているかも知れない}

植物が外界からの刺激 (シグナル)をどのよらに受容 しそそれに対してどのよらに応答するかについてはほと んど知られていないが，模式的に画けば次のようにな ๖.

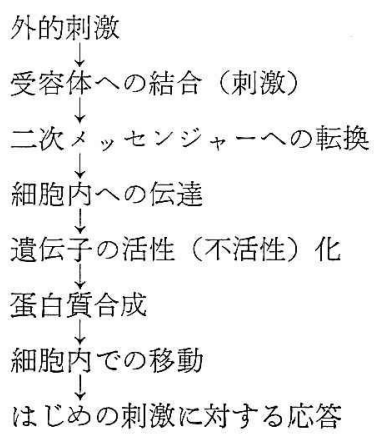

ras 関連遺伝子産物は，この経路のどこかに組み迈ま れていると考学らる. 矮性もまた，この系のどこかに 異常があるため起こるとも解积される. ホルモン受容体
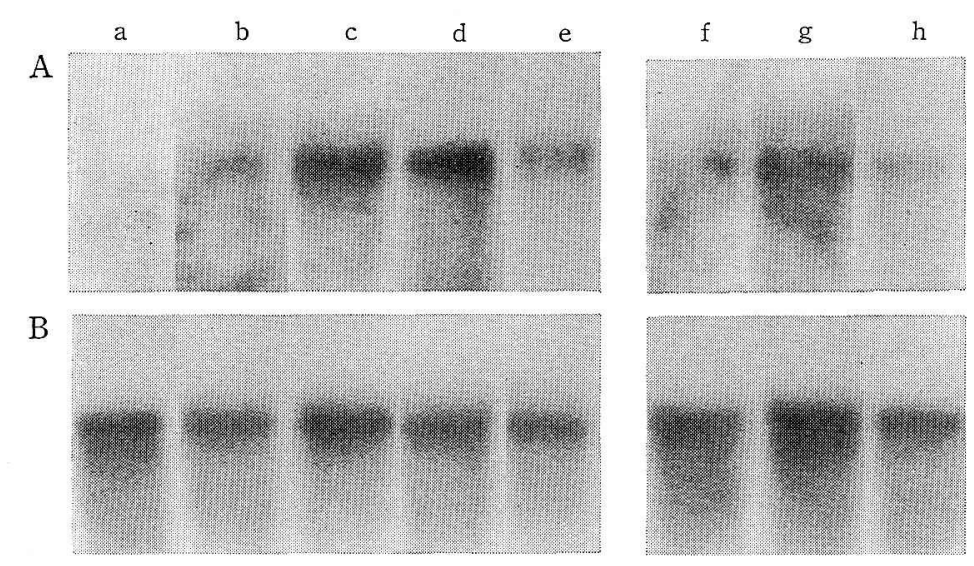

図 4ロイネの生育中における $r g p I$ 遺伝子の発現

全RNA を電気泳動で分画後, ナイロン膜に転写し， ${ }^{32} \mathrm{P} て ゙$ 標識した $r g p 1 \mathrm{cDNA}$ (A) あるいはイネアクチンの cDNA (B) でノーザンハイブリダイゼーションを行なった. RNA の抽出時期は未処理種子の発芽後 10 日 (a)，2 週間 (b)，4 週間 (c)，6 週間 (d) および 9 週間 (e), azaC 処理種子の発芽後 2 週間 $(f), 4$ 週間 $(g)$ お よび 6 週間 (h). 詨照苗, $\mathrm{azaC}$ 処理苗とすに 発芽後 4 6 週閒で $r g p$ I が最大に 発現されていることがわかる.さらにその発現量は azaC 処理苗で低下していることむ うかがえる.このようなステージ特異的な発現が rgp 1 特有であることは, 構造的に 発現されているアクチン mRNA の量が全ステージを通してほぼ一定であることから 確認できる(11). 
異常 (トウモロコシ D 8 など) はその例である. そこで 筆者らの得たイネ ras 関連遺伝子, $r g p 1$ がこのような シグナル応答系, さらには矮性発現に関与しているかど らかを調べた。まず，イネ幼植物の生育段階での発現を mRNA ハイブリダイゼーションノノーザンハイブリダイ ゼーション)法で分析した(図 4). 対照苗では rgp 1 は発 芽後 2 週間くらいから発現され始め, $4 \sim 6$ 週間目で最 大になり，その後，徐々に減少する. azaC 処理苗でも同 じ傾向であるが全体的に発現量が低下していることがわ かる. 矮性 $\mathrm{M}_{4}$ でも $r g p I$ は矮性親同様, 減少していた ので $\operatorname{rgp} 1$ は矮性と相関していることが知られた．この ことは生物学的に $2 つ の$ 点で重要である. 第一に rgp 1 の生長へ関与, 第二に DNA メチル化による $r g p I$ 遺伝 子の発現調節, である.

イネ苗に沶いて発芽後 4 〜 週間で生理的にどのよう な変化が起こるかははっきりしないが，一般的には分げ つが起こり，生長が盛んな時期である(15). 生長にはもち ろん各種ホルモンが関与しているが, 分げつにも少なく ともジベレリンは関わっているらしい，たとえば，矮性 コムギ $R h t 3$ は GA 非感受性であるが，GA 投与によ って分げつが促進されることがわかっている， $\operatorname{rgp1}$ が 生長の盛んな時にのみ特異的に発現されること, $\mathrm{azaC}$ 誘導の矮性苗ではその発現量が少ないことなどの結果を 考えあわせると， $\operatorname{rgp} 1$ はイネの生長に関係する遺伝子 の一つである可能性が高い。とすれば， ras 遺伝子産物 の特徴から考えてホルモンなどの受容・転換・伝達系の ぞこかに位置するのではないだろらか.すなわち，外部 シグナルを細胞内メッセンジャーに転換し，転写調節因 子まで伝える系のどこかに関与しているのではないだろ らか.こうした推定を証明するためには, トランスジェ ニック植物を作って $\operatorname{rgp} 1$ の発現異常が本当に形態異常 をひき起こすかどらかを調べなければならない，しか し，それと同時に $\operatorname{rgp} 1$ を起点として $\operatorname{rgp} 1$ に結合する 蛋白質, さらにその蛋白質に相互作用する別の蛋白質, さらにその上の蛋白質, といった具合に追っていけば植 物生長制御物質の受容体やDNA 転写調節因子までたど り着けるかも知れない。

このようなシグナル伝達カスケードの目まぐるしい switch-on/off の一つの調節因子として DNA メチル 化が具体的な可能性を持って登場してきた. もし一般 に考えられているよらに，DNAメチル化が遺伝子の switch-off に連動しているのなら, azaC による脱メチ ル化が直接 $r g p 1$ の発現を抑えた, とするには無理があ る. 屯しろ $\operatorname{rgp} 1$ の silencer element（抑制遺伝子）の 発現が脱メチル化によって促進され, その作用で $r g p I$ 発現が落ちたと考えるほうがよいかも知れない.こうし た問題点も含めて，rgp 1 を中心に実験の輪を広げるこ とによって，これまで未知であった植物に拈ける矮性発 現やシグナル応答, 遺伝子発現調節機構などの解明に進 めるのではないか，というのが現在の筆者らの作業仮説 であり希望である.

謝辞 : 本稿執筆の機会を与支て下さいました勝見允行教授（国 際基督教大学)，一連の実験に携わっていただいた研究室のメ ンバー (S. Youssefian 講師, 鎌田郁子, 山内聖子, 伊藤征樹 のテクニシャン諸氏, 秋田県立農短大・生物工学研究所), 原 稿のタイプ構成を受けもっていただいた二田好子氏（同所）に 深く感謝の意を表します.

\section{文献}

1) B. Lewin : "Genes IV", Oxford Univ. Press, Oxford, 1990.

2) J. Braam \& R. W. Davis : Cell, 60, 357 (1990).

3）西澤 誠：化学と生物，27，493 (1989),

4) R. M. Evans \&_S. M. Hollenberg: Cell, 52, 1 (1988).

5) 佐野 浩: 細胞工学, 2, 1493 (1983).

6) R. L.P. Adams \& R.H. Burdon : "Molecular Biology_of DNA Methylation", Springer-Verlag, New York, 1985.

7) A. Razin, H. Cedar \& A. D. Riggs : "DNA Methylation", Springer-Verlag, New York, 1984.

8) 佐野 浩ら：化学と生物, 27, 2 (1989).

9) H. Sano et al.: Mol. Gen. Genet., 220, 441 (1990).

10）蓬原雄三: “イネの育種学”, 東京大学出版会, 1990.

11) H. Sano \& S. Youssefian: Mol. Gen. Genet., in press. (1991).

12）宇井理生ら：“GTP 結合蛋白質と情報伝達”, 羊土社, 1990 .

13）岡田節人ら：“情報の 伝達と物質の動き II”, 岩波畫占, 1990.

14) R. Hilson et al.: Plant Mol.Biol., 14, 669 (1990).

15）松尾孝嶺ら：“稲学大成 I”, 農文協, 1990.

16) S. Miyake \& M. Yamamoto: EMBO J., 9, 1419 (1990).

17) M. Matsui et al.: Gene, 76, 331 (1989).

\section{教官公募}

\section{名古屋大学農学部 助手}

名古屋大学農学部では, 食品工業化学科食品製造化学第二講 座助手を公募しています. 蛋白質が関与する食品機能の解明を 志向する 30 歳くらいまでの方を求めています. 応募締め切り は本年 9 月 2 日 (月) です.

詳細は下記にお問い合わせ下さい。

于464-01 名古屋市千種区不老町 名古屋大学農学部 食品製造化学第二講座助手選考委員会

委員長 中村 良

\% 052-781-5111（内線 6296) 